\title{
AN EMPIRICAL NOTE ON THE TERM STRUCTURE AND INTEREST RATE STABILIZATION POLICIES
}

\author{
Peter Kugler
}

\section{INTRODUCTION}

The expectations theory of the term structure of interest rates supplemented by the rational expectations and time-invariant risk premium assumption implies that the spread between the long and the short rate has in general predictive power for the short rate. This implication was consistently rejected in recent studies [Shiller, Campbell, and Schoenholtz, 1983; Fama, 1984; Mankiw and Summers, 1984] with data at the short end of the maturity spectrum (three- and six-month treasury bills). Time variations of the risk premium, which are probably important for the behavior of the yield on long-term bonds, are not an entirely satisfactory explanation for these findings. In a more recent article of Mankiw and Miron [1986], who analyzed quarterly data for three- and six-month interest rates over the period 1890-1979, an interesting new explanation for the failure of the expectations theory emerged. They showed that the spread had substantial predictive power for changes in the short rate in the period before the founding of the Federal Reserve (1890-1914), whereas for all other periods considered (1915-1933, 1934-1951, 1951-1958, and 1959-1979), the spread did not help to predict the short rate. Thus, Mankiw and Miron suggested that the rejection of the expectations theory with recent data is a consequence of the commitment of the Federal Reserve to stabilize interest rates resulting in random walk behavior of the short rate. Under these circumstances, expected future short rates are equal to the actual short rate and variations of the spread are only brought about by changes in the risk premium.

In this note the short-term interest rate stabilization explanation for the failure of the predictive implications of the expectations theory of the term structure is subjected to an additional empirical test using recent monthly data. Thereby, the short end of the term structure of Swiss, German, and U. S. interest rates is analyzed for the years 1974-1986. These three cases are of great interest in our context. The Swiss National Bank and the German Federal Bank used the opportunity offered by the flexible exchange rate system to implement money supply targets and did not attempt to stabilize short-term interest rates, whereas the Federal Reserve was at

- 1988 by the President and Fellows of Harvard College and the Massachusetts Institute of Technology.

The Quarterly Journal of Economics, November 1988 
least until 1979 strongly committed to interest rate stabilization policies.

\section{RESULTS}

The linearized version of the term structure equation relates the three-period (long-term) interest rate $R_{t}$ to the one-period (short-term) interest rate $r_{t}$ by the following equation:

$$
R_{t}=1 / 3\left(r_{t}+r_{t+1}^{e}+r_{t+2}^{e}\right)+\theta \text {. }
$$

Thereby, $r_{t+j}^{e}$ stands for the expected value of $r_{t+j}$ given information available at period $t$ and $\theta$ is a constant risk premium. Under the rational expectations assumption, $r_{t+j}^{e}$ is given by $E\left(r_{t+j} \mid I_{t}\right)$, where $I_{t}$ symbolizes the information available at period $t$.

The approach to test the implications of this theoretical framework applied by Mankiw and Miron to the two-period term structure is easily extended to the case in hand: multiplying (1) by 3 and subtracting $3 r_{t}$ on both sides results in

$$
r_{t+2}^{e}+r_{t+1}^{e}-2 r_{t}=\Delta r_{t+2}^{e}+2 \Delta r_{t+1}^{e}=-3 \theta+3\left(R_{t}-r_{t}\right) .
$$

Variations of the spread $R_{t}-r_{t}$ reflect, therefore, expected short rate changes for the next two periods.

If we replace $r_{t+j}^{e}$ by $r_{t+j}$ minus the expectation error $\epsilon_{t+j}^{j}$, we obtain an equation in observables:

$$
\left(r_{t+2}+r_{t+1}-2 r_{t}\right)=-3 \theta+3\left(R-r_{t}\right)+\xi_{t+2} .
$$

Under rational expectations, the error term $\xi_{t+2}=\epsilon_{t+2}^{2}+\epsilon_{t+1}^{1}$ is uncorrelated with information dated $t$ and earlier and follows an MA(1) process. According to this property, equation (3) can be consistently estimated by a simple OLS regression, but the OLS covariance matrix estimate is inconsistent. Instead, one has to use the asymptotically correct covariance matrix estimate proposed by Hansen [1982].

Equation (3) is estimated using monthly end-of-period data for the period 1974/1 to $1986 / 8$ and for the United States, West Germany, and Switzerland. ${ }^{1}$ The underlying assets are Euromarket deposits which are the most important short-term financial instruments in the Swiss case. For the U. S. data, the sample is split into

1. The data source for the Swiss rates is the monthly data tape of the Swiss National Bank. The U. S. and German data were supplied by the DRI data bank FACS which were kindly made available by the Swiss Bank Corporation, Economics Division. 
TABLE I

Test of Predictive Power of the Spread for Future Short Rate Changes:

OLS ESTIMATES

\begin{tabular}{lcccc}
\hline & $\left(\Delta r_{t+2}+2 \Delta r_{t+1}\right)=\alpha_{0}+\alpha_{1}\left(R_{t}-r_{t}\right)+\xi_{t+2}$ & & \\
\hline & $\alpha_{\mathrm{o}}$ & $\alpha_{1}$ & $R^{2}$ & S.E. \\
\hline United States & 0.12 & 0.096 & 0.0004 & 1.86 \\
1974/3-1979/9 & $(0.38)$ & $(0.68)$ & & \\
United States & -0.50 & 1.19 & 0.025 & 3.45 \\
1980/3-1986/8 & $(0.52)$ & $(1.03)$ & & \\
West Germany & -0.49 & 2.81 & 0.158 & 1.44 \\
1974/3-1986/8 & $(0.18)$ & $(0.53)$ & & \\
Switzerland & -0.70 & 1.51 & 0.095 & 2.07 \\
1974/3-1986/8 & $(0.29)$ & $(0.53)$ & & \\
\hline \hline
\end{tabular}

Estimated [Hansen] standard errors are given in parentheses.

S.E. is the estimated standard error of $\xi$.

subperiods, namely 1974/1-1979/9 and 1980/1-1986/8. The procedure is, of course, motivated by the change in U. S. monetary policy that took place in autumn 1979.

The results given in Table I indicate that the spread has predictive power for short rate changes in the German and Swiss cases; whereas this is not true for the United States in both subperiods. The estimate of $\alpha_{1}$ is significantly lower than the theoretical value of three in the Swiss equation, while in the German case the hypothesis $\alpha_{1}=3$ cannot be rejected at conventional significance levels. The results for Switzerland, West Germany, and the United States for the period 1974-1979 confirm the results of Mankiw and Miron. In a framwork of money supply targeting, the predictive power of the spread for the short rate implied by the expectations theory is found, whereas this is not true for circumstances of interest rate stabilization. The fact that there is no statistically significant predictive power of the spread for the short rate after the change in operating procedures of U. S. monetary policy in October 1979 seems to be at odds with these findings. However, the analysis of Goodfriend, Anderson, Kashyap, Moore, and Porter [1986] shows that the new operating procedure includes several elements, which continue to smooth or stabilize short-term interest rates. In addition, the FED did not stick to a strict policy of money supply targeting for long. In October 1982 the money supply target was deemphasized, and interest rates regained their importance as the primary target of monetary policy. Finally, 
the parameter estimates for the second period are, although not significantly different from zero, more in line with the theory.

\section{CONCLUSION}

In this note the interest rate stabilization explanation of the empirical failure of the expectations theory of the term structure of interest rates at the short end of the maturity spectrum suggested recently by Mankiw and Miron [1986] is subjected to an additional empirical test. As the Swiss National Bank and the German Federal Bank followed mainly a money supply target policy since 1973; whereas the FED was, at least until 1979, strongly committed to stabilizing short-term interest rates, it is useful to test this hypothesis with recent Swiss, German, and U. S. data. The analysis of monthly end-of-period time series of one-month and three-month interest rates for the years 1974-1986 shows statistically highly significant predictive power for the short rate in the Swiss and German cases, while this does not apply to the United States. Thus, our empirical analysis presents additional evidence in favor of the argument put forward by Mankiw and Miron. Finally, it may be worth mentioning that the expectations theory fails to explain the short end of the maturity spectrum of U.S. interest rates before and after the change in the operating procedures of monetary policy of October 1979. This result has to be explained by interest rate smoothing element of the new procedure as well as by the fact that in October 1982 the FED again deemphasized the money supply target, and interest rates regained their importance as the main target of monetary policy.

UNIVERSITY OF BERN, SWITZERLAND

\section{REFERENCES}

Fama, E. F. "The Information in the Term Structure," Journal of Financial Economics, XIII (1984), 509-28.

Goodfriend, M., G. Anderson, A. Kashyap, G. Moore, and R. D. Porter, "A Weekly Rational Expectations Model of the Nonborrowed Reserve Operating Procedure," Economic Review, LXXII (1986), Federal Reserve Bank of Richmond, 11-28.

Hansen, L. "Large Sample Properties of Generalized Method of Moments Estimators," Econometrica, L (1982), 1029-54.

Mankiw, N. G., and J. A. Miron, "The Changing Behavior of the Term Structure of Interest Rates," this Journal, CI (1986), 211-28.

Mankiw, N. G., and L. H. Summers, "Do Long-Term Interest Rates Overreact to Short-Term Interest Rates?" Brookings Papers on Economic Activity (1984), 223-43.

Shiller, R. J., J. Y. Campbell, and K. L. Schoenholtz, "Forward Rates and Future Policy: Interpreting the Term Structure of Interest Rates," Brookings Papers on Economic Activity (1983), 173-217. 